\title{
Effect of land use on mayfly assemblages structure in Neotropical headwater streams
}

\author{
ANA EMILIA SIEGLOCH ${ }^{1,2}$, MARCIA SURIANO ${ }^{3}$, MARCIA SPIES ${ }^{4}$ and ALAÍDE FONSECA-GESSNER ${ }^{3}$ \\ ${ }^{1}$ Programa de Pós-Graduação em Ecologia, Universidade Federal de Santa Catarina, \\ Centro de Ciências Biológicas, Departamento de Ecologia e Zoologia, Campos Universitário, s/n, \\ Bairro Córrego Grande, 88040-900 Florianópolis, SC, Brasil \\ ${ }^{2}$ Programa de Pós-Graduação em Ambiente e Saúde, Universidade do Planalto Catarinense, \\ Av. Castelo Branco, 170, Bairro Universitário, 88509-900 Lages, SC, Brasil \\ ${ }^{3}$ Universidade Federal de São Carlos, Departamento de Hidrobiologia, \\ Rod. Washington Luiz, Km 235, 13565-905 São Carlos, SP, Brasil \\ ${ }^{4}$ Universidade Federal do Pampa, Campus São Gabriel, Av. Antônio Trilha, 1847, 97300-000 São Gabriel, RS, Brasil
}

Manuscript received on December 16, 2013; accepted for publication on May 2, 2014

\begin{abstract}
The aim of this study was to test the effect of agricultural and forestry land use on the structure of mayfly assemblages in low-order streams. Twenty-nine headwater streams were investigated in the state of São Paulo. We analyzed 15 streams in pristine areas (mixed tropical rainforest, semideciduous forest and dense tropical rainforest), and 14 streams covered with sugarcane, eucalyptus and pasture. Mayfly richness obtained by rarefaction curves was higher in pristine areas ( 21 genera), especially in mixed and semideciduous forest when compared to land use (9 genera), where values were particularly low in sugarcane plantation (3 genera). The non-metric multidimensional scaling (NMDS) ordination showed clear difference in mayfly assemblages between land uses and pristine areas, supported by analysis of similarity $(\mathrm{R}=0.67, \mathrm{p}=0.001)$. In partial redundancy analysis ( $\mathrm{pRDA})$, the environmental descriptors that best explained differences in assemblage structure were Riparian, Channel and Environmental Inventory (RCE) index score, percentage of fine sediment stream substrate, water $\mathrm{pH}$ and land elevation. Our results show that agricultural and forestry land use has a strong negative effect on the structure of mayfly assemblages. These results also support the use of mayflies as environmental indicators, as some genera were sensitive to changes in land use, while others responded to naturally occurring changes in the study area.
\end{abstract}

Key words: Atlantic forest, environmental integrity, Ephemeroptera, richness, aquatic insects.

\section{INTRODUCTION}

Anthropogenic actions, such as change in land use, have influenced most ecosystems in the world, via alteration of assemblage structure, resulting in a loss of species diversity and disturbances that can alter ecosystem functions (Allan et al. 2004).

Correspondence to: Ana Emilia Siegloch

E-mail: asiegloch@gmail.com
Environmental modifications such as habitat fragmentation and the removal and substitution of riparian forest, have a negative effect on the input of organic material, and change the composition of allochthonous material that constitutes the energy source, the shelter and the food of headwater streams biota (Dudgeon et al. 2006, França et al. 2009). Changes in land use also produce changes 
in the hydrology, physical habitat and water quality of streams, leading to a drastic reduction in biodiversity (Nessimian et al. 2008).

The increased extent of agricultural land in southeastern Brazil caused suppression of native forest, directly and negatively affecting water quality, physical habitat and biota of many streams (Corbi and Trivinho-Strixino 2008, Kleine et al. 2012). In this region, there has been strong expansion of exotic monocultures such as pine and eucalyptus, used in the wood and paper industry, and sugarcane to produce sugar and fuel alcohol. These monocultures contribute to deforestation and the fertilizers and pesticides applied to these crops contaminate soil and water with metals and chemical ions (Corbi et al. 2006). Land conversion to pasture has also caused disturbance, because the grazing cattle trample the river channel, causing bank erosion and increasing water temperature and nutrient input (Fernández et al. 2009). Currently in the state of São Paulo, natural forests (Atlantic rainforest) are found in fragmented areas, mainly in Conservation Units (CUs) that serve as 'reference areas', inserted in regions dominated by extensive monocultures and pastures.

Among the benthic invertebrate assemblages, immature mayfly assemblages are important because of their high species richness and abundance, and wide distribution among aquatic habitats. These insects play an important role in nutrient cycling in the aquatic environment, because they process large amounts of organic matter originating from riparian vegetation and periphyton (Moulton et al. 2004, Domínguez et al. 2006). The Ephemeroptera, together with Trichoptera and Plecoptera are also considered key biological indicators of water quality, due to their sensitivity to pollution and habitat fragmentation (Rosenberg and Resh 1993).

Several studies have shown a reduction in the diversity and richness of aquatic fauna in areas affected by human interference especially in areas used for monoculture farming and pasture. For example, Nessimian et al. (2008) evaluated the effects of forest cover changes on the aquatic insects assemblages in Amazonian streams, comparing exposed soil, pastures, secondary forests and primary forests. They found that drastic changes in the vegetation cover seemed to induce significant changes in aquatic insect assemblages, especially in Ephemeroptera, Plecoptera, and Trichoptera (EPT), whose richness was significantly lower in pasture streams; and the taxonomic composition of streams in forested areas was also significantly different from streams in open areas. Corbi et al. (2013) also showed that in the southeastern state of São Paulo, forested streams had higher richness and diversity of EPT and Coleoptera than banana plantation streams.

In the present study, the aim was to test differences in the structure of mayfly assemblages in low-order streams due to changes in riparian vegetation cover. Sample streams were selected in pristine forest (mixed tropical rainforest, semideciduous seasonal forest and dense tropical rainforest) and on land used for agricultural and forestry purposes (sugarcane monoculture, pasture, eucalyptus plantations). Additionally, we identified the relative contribution of environmental descriptors of mayfly assemblages in streams on pristine forest vs. land use areas. We hypothesized that due to the sensitivity of immature mayflies to environmental changes, genera richness and diversity would be higher in pristine forest streams.

\section{MATERIALS AND METHODS}

The study was carried out in the state of São Paulo, southeastern Brazil, in a tropical region, with a mean annual temperature of $16-18^{\circ} \mathrm{C}$ and mean annual rainfall between 1,000 and 1,400 $\mathrm{mm}$ (SOS Mata Atlântica / INPE 1993). One of the main problems impeding efforts to preserve the remaining native forest in this state is the great extent of fragmentation (Myers et al. 2000). At present, a total of $88 \%$ of the original Atlantic rainforest 
has been lost and only $12 \%$ of the natural forest remains (Ribeiro et al. 2009). The landscape consists of a mosaic of land uses, with small patches of forest on hilltops or in other remote areas surrounded by extensive monoculture (e.g. sugarcane and eucalyptus plantations) and pasture.

\section{DATA COLLECTION}

In this study, we chose 29 small (first and second order) streams, 15 of which are located in Conservation Units (CUs), identified as follows: Parque Estadual de Campos do Jordão (S1, S2,
S3, S4 and S5) - mixed tropical rainforest; Estação Ecológica Caetetus (S6), Parque Estadual Furnas do Bom Jesus (S7 and S8), Parque Estadual Vassununga (S9), Parque Estadual do Morro do Diabo (S10, S11 and S12) - semideciduous seasonal forest and Parque Estadual Intervales (S13, S14 and S15) - dense tropical rainforest. Fourteen streams were selected in agricultural and forestry lands, areas identified as follows: sugarcane monoculture (S16, S17, S18, S19 and S20), pasture (S21, S22, S23, S24 and S25) and eucalyptus plantations (S26, S27, S28 and S29) (Figure 1).

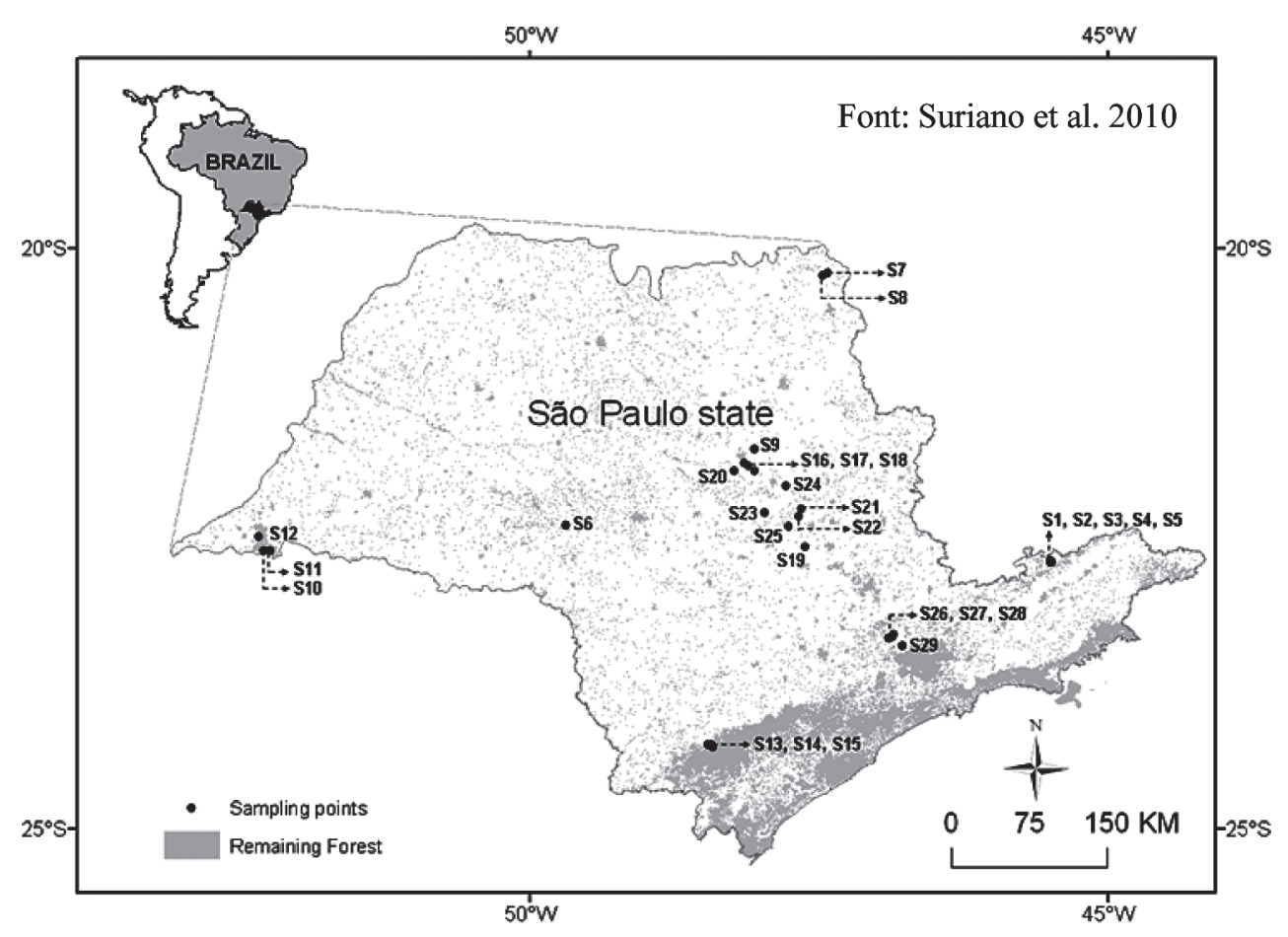

Figure 1 - Map of São Paulo state, Brazil, showing locations of stream sampling sites. Streams in pristine areas are: S1, S2, S3, S4, S5 (Parque Estadual de Campos de Jordão) in mixed tropical rainforest; S6 (Estação Ecológica Caetetus), S7, S8 (Parque Estadual Furnas do Bom Jesus), S9 (Parque Estadual de Vassununga), S10, S11, S12 (Parque Estadual Morro do Diabo) in semideciduous seasonal forest; $\mathrm{S} 13, \mathrm{~S} 14, \mathrm{~S} 15$ (Parque Estadual Intervales) in dense tropical rainforest. Streams in land use areas are: S16, S17, S18, S19, S20 (sugarcane); S21, S22, S23, S24,S25 (pasture) and S26, S27, S28 and S29 (eucalyptus) (Suriano et al. 2010).

Selected streams were completely contained in the area of the specificed land use. Ephemeroptera were collected with a Surber sampler $\left(0.1 \mathrm{~m}^{2}\right.$ area and $250 \mu \mathrm{m}$ mesh size) during the dry seasons of
2005 and 2006. Six Surber sampling units were collected randomly along a $100 \mathrm{~m}$ stretch of each stream. Specimens were identified to the lowest practicable taxonomic level, using published books 
(Domínguez et al. 2006, Domínguez and Fernández 2009) and a taxonomic article (Salles et al. 2004).

Environmental descriptors were recorded at each site to characterize habitat conditions and human disturbances. In three different sections of each site, electrical conductivity, dissolved oxygen concentration, $\mathrm{pH}$ and temperature of the water, were measured with a multiprobe; water velocity was measured by the float method (Bain and Stevenson 1999); the depth and width of streams were determined with a measuring tape; and land elevation was determined by GPS. The mean of the three measurements for each variable was used in the analysis. The predominant substrate types were estimated visually according to Ward (1992).

Seven metrics and their scores from the Riparian, Channel and Environmental Inventory (RCE) for small streams (Petersen 1992) were used to assess the physical and biological conditions in the riparian zone, and stream channel morphology. Each metric varies from 1 (most degraded condition) to 30 (best condition). The RCE final score for each stream represented the sum of the scores for the following metrics: 1) land use pattern beyond the immediate riparian zone; (2) the width of riparian zone from stream edge to field; (3) the completeness of the riparian zone; (4) vegetation of riparian zone within $10 \mathrm{~m}$ of channel; (5) retention devices; (6) channel sediments and (7) stream-bank structure.

DATA ANALYSIS

The rarefaction method was used to construct genera accumulation curves and compare richness between pristine and land use areas, as well as to determine difference among vegetation types, rescaled by abundance. The rarefaction method is based on the premise that assemblages must be sufficiently sampled in order to be compared (Magurran 2011). Mayfly samples were organized in two blocks (or treatments): state of conservation (pristine and land use areas) and vegetation types (mixed tropical rainforest, semideciduous seasonal forest, dense tropical rainforest, pasture, sugarcane and eucalyptus). The comparison of richness was conducted at the highest comparable abundance level among assemblages (840 individuals for state of conservation; 95 individuals for different vegetation types) (Gotelli and Entsminger 2001). Rarefaction curves were generated based on 1,000 randomizations by the program EcoSim 700 (Gotelli and Entsminger 2001).

Assemblages structure was analyzed through the Bray-Curtis similarity coefficient and represented by non-metric multidimensional scaling (NMDS). Stress values below 0.2 represent a good adjustment of ordination (Clarke and Warwick 2001). Analysis of similarity (ANOSIM - one way) was used to test the difference between stream samples in pristine and land use areas, using the permutation method on the resemblance matrix.

The partial redundancy analysis (pRDA) was used to assess the influence of the environment variables on the mayfly assemblages and to remove the effect of the spatial autocorrelation of samples. The geographical coordinates (latitude, longitude) of the streams were measured using a GPS. Next, spatial variables were generated using the principal coordinates of neighbor matrices (PCNM) methods described by Borcard and Legendre (2002). The PCNM approach allows assessment of the spatial structure of the geographical sampling area, by calculating a truncated Euclidean distance matrix from the geographical coordinates of the sampling sites and performing a principal components analysis to extract eigenvectors from the matrix, which can be used as predictor variables or covariates in analysis (Borcard and Legendre 2002). PCNM analyses were performed with SAM 4.0 (Rangel et al. 2010).

Two redundancy analyses were run using manual forward selection and alpha-value $\mathrm{p}<0.05$ to select the variables to be included in the model. First, we ran an RDA of the mayfly genera data matrix explained by environmental variables, then we performed a second RDA analysis with the mayfly genera data matrix and spatial variables (PCNM). 
After, a pRDA was performed with the environmental variables selected, with spatial variables (alpha-value $\mathrm{p}<0.05$ ) as covariates to remove spatial autocorrelation effects in the program CANOCO 4.5 (Ter Braak and Smilauer 2002).

Of the 29 sampled streams, two streams (S17 and S18) located in sugarcane cultivation had no immature mayflies and were removed from all statistical analyses. Mayfly abundance of the six sampling units in each stream was pooled, resulting in 27 samples. The biotic data were Hellinger transformed and environmental data were squareroot transformed (percentage variables were arcsine transformed) and standardized (by standard deviation). Transformations were necessary to reduce the influence of large abundance differences and double zeros, to normalize and render data homoscedastic (Clarke and Gorley 2006) Standardization was used to account for differences in units of the environmental variables measured (Clarke and Gorley 2006).

\section{RESULTS}

Pristine area streams had substrate composed mainly of boulders, gravel and sand and strong habitat diversity provided by the accumulation of leaves, while the streams in land use areas were characterized by homogeneous substrate. Dissolved oxygen was present in high concentrations in all streams in pristine $(9.3 \pm 1)$ and in land use areas (8.2 \pm 1.1$)$. Electric conductivity in both areas was low, with the exception of dense rainforest streams (56 - $204 \mu \mathrm{S}, \mathrm{cm}^{-1}$ ), pasture stream S22, eucalyptus plantation streams S27 and S28. Values of $\mathrm{pH}$ were close to neutral (6.3 to 7.1) in pristine areas, with the exception of dense rainforest, which was alkaline (12.5 - 13.1); and in land use streams, they were more acidic, with the exception of pasture stream S22 and eucalyptus plantation stream S28. Water velocity and RCE values were low in land use streams. The values of these components and other measurements of physical and chemical characteristics are presented in Table I.

TABLE I

Environmental characterization of streams sampled in pristine areas: S1, S2, S3, S4, S5 (Parque Estadual de Campos de Jordão) in mixed tropical rainforest; S6 (Estação Ecológica Caetetus), S7, S8 (Parque Estadual Furnas do Bom Jesus), S9 (Parque Estadual de Vassununga), S10, S11, S12 (Parque Estadual Morro do Diabo) in semideciduous seasonal forest; S13, S14, S15 (Parque Estadual Intervales) in dense tropical rainforest. Streams in land use areas are: S16, S17, S18, S19, S20 (sugarcane plantations); S21, S22, S23, S24, S25 (pasture) and S26, S27, S28 and S29 (eucalyptus plantations). (Cond = electrical conductivity, DO = dissolved oxygen, Fine sed. $=$ fine sediment, Land $=$ Land Elevation, Vel $=$ water velocity, $\mathbf{R C E}=$ Riparian, Channel and Environmental inventory).

\begin{tabular}{|c|c|c|c|c|c|c|c|c|c|c|c|c|}
\hline Areas & Stream & Coordinate & pH & $\begin{array}{c}\text { Cond } \\
\mu \mathrm{S}\end{array}$ & $\begin{array}{c}\text { DO } \\
\mathrm{mg} / \mathrm{l}\end{array}$ & $\begin{array}{c}\text { Boulder } \\
\%\end{array}$ & $\begin{array}{c}\text { Gravel } \\
\%\end{array}$ & $\begin{array}{c}\text { Sand } \\
\%\end{array}$ & $\begin{array}{c}\text { Fine } \\
\text { Sed. \% }\end{array}$ & $\begin{array}{c}\text { Land } \\
\text { m }\end{array}$ & $\begin{array}{l}\text { Vel } \\
\mathrm{m} / \mathrm{s}\end{array}$ & RCE \\
\hline Mixed & S1 & $\begin{array}{l}22^{\circ} 41^{\prime} 35^{\prime \prime} \mathrm{S} \\
45^{\circ} 29^{\prime} 23^{\prime \prime} \mathrm{W}\end{array}$ & 6.98 & 11.4 & 8.26 & 5 & 25 & 60 & 10 & 1554 & 0.5 & 180 \\
\hline Mixed & S2 & $\begin{array}{l}22^{\circ} 41^{\prime} 35^{\prime \prime} \mathrm{S} \\
45^{\circ} 29^{\prime} 23^{\prime \prime} \mathrm{W}\end{array}$ & 6.7 & 11.8 & 8.46 & 10 & 40 & 40 & 10 & 1500 & 0.2 & 180 \\
\hline Mixed & S3 & $\begin{array}{l}22^{\circ} 41 ' 53^{\prime \prime} \mathrm{S} \\
45^{\circ} 29^{\prime} 02^{\prime \prime} \mathrm{W}\end{array}$ & 6.58 & 16.3 & 8.65 & 5 & 40 & 50 & 5 & 1580 & 0.4 & 180 \\
\hline Mixed & S4 & $\begin{array}{l}22^{\circ} 41^{\prime} 51^{\prime \prime} \mathrm{S} \\
45^{\circ} 29^{\prime} 20^{\prime \prime} \mathrm{W}\end{array}$ & 6.56 & 11.6 & 8.54 & 10 & 40 & 40 & 10 & 1556 & 0.3 & 180 \\
\hline Mixed & S5 & $\begin{array}{l}22^{\circ} 41 ' 56 " \mathrm{~S} \\
45^{\circ} 29 ' 19, \mathrm{~W}\end{array}$ & 6.56 & 12.1 & 8.47 & 20 & 40 & 30 & 10 & 1555 & 0.3 & 180 \\
\hline Semideciduous & S6 & $\begin{array}{l}22^{\circ} 23^{\prime} 11^{\prime \prime} \mathrm{S} \\
49^{\circ} 41^{\prime} 10^{\prime \prime} \mathrm{W}\end{array}$ & 7.14 & 70 & 10.8 & 0 & 40 & 50 & 10 & 663 & 0.1 & 180 \\
\hline
\end{tabular}


TABLE I (Continuation)

\begin{tabular}{|c|c|c|c|c|c|c|c|c|c|c|c|c|}
\hline Areas & Stream & Coordinate & pH & $\begin{array}{c}\text { Cond } \\
\mu S\end{array}$ & $\begin{array}{c}\text { DO } \\
\mathrm{mg} / \mathrm{l}\end{array}$ & $\begin{array}{c}\text { Boulder } \\
\%\end{array}$ & $\begin{array}{c}\text { Gravel } \\
\%\end{array}$ & $\begin{array}{c}\text { Sand } \\
\%\end{array}$ & $\begin{array}{c}\text { Fine } \\
\text { Sed. \% }\end{array}$ & $\begin{array}{c}\text { Land } \\
\mathrm{m}\end{array}$ & $\begin{array}{l}\mathrm{Vel} \\
\mathrm{m} / \mathrm{s}\end{array}$ & RCE \\
\hline Semideciduous & S7 & $\begin{array}{c}20^{\circ} 12^{\prime} 07^{\prime \prime} \mathrm{S} \\
47^{\circ} 24^{\prime} 58^{\prime \prime} \mathrm{W}\end{array}$ & 8.08 & 25 & 9.85 & 50 & 30 & 10 & 10 & 649 & 0.3 & 185 \\
\hline Semideciduous & S8 & $\begin{array}{l}20^{\circ} 13^{\prime} 46^{\prime \prime} \mathrm{S} \\
47^{\circ} 27^{\prime} 37^{\prime \prime} \mathrm{W}\end{array}$ & 7.03 & 33 & 7.85 & 50 & 30 & 10 & 10 & 895 & 0.2 & 185 \\
\hline Semideciduous & S9 & $\begin{array}{l}21^{\circ} 43^{\prime} 14^{\prime \prime} \mathrm{S} \\
48^{\circ} 02^{\prime} 53^{\prime \prime} \mathrm{W}\end{array}$ & 6.71 & 10 & 10.2 & 0 & 50 & 40 & 10 & 741 & 0.2 & 145 \\
\hline Semideciduous & $\mathrm{S} 10$ & $\begin{array}{c}22^{\circ} 36^{\prime} 16^{\prime \prime} \mathrm{S} \\
52^{\circ} 18^{\prime} 02^{\prime \prime} \mathrm{W}\end{array}$ & 6.84 & 30 & 10.4 & 0 & 80 & 10 & 10 & 279 & 0.6 & 180 \\
\hline Semideciduous & S11 & $\begin{array}{c}22^{\circ} 35^{\prime} 55^{\prime \prime} \mathrm{S} \\
52^{\circ} 14^{\prime} 47^{\prime \prime} \mathrm{W}\end{array}$ & 6.32 & 10 & 10.3 & 0 & 40 & 50 & 10 & 234 & 0.3 & 180 \\
\hline Semideciduous & $\mathrm{S} 12$ & $\begin{array}{c}22^{\circ} 28^{\prime} 34^{\prime \prime} \mathrm{S} \\
52^{\circ} 20^{\prime} 34^{\prime \prime} \mathrm{W}\end{array}$ & 6.56 & 20 & 10.2 & 0 & 0 & 90 & 10 & 277 & 0.3 & 180 \\
\hline Dense & $\mathrm{S} 13$ & $\begin{array}{c}24^{\circ} 17^{\prime} 48^{\prime \prime} \mathrm{S} \\
48^{\circ} 25^{\prime} 03^{\prime \prime} \mathrm{W}\end{array}$ & 13.1 & 56 & 5.9 & 0 & 60 & 35 & 5 & 850 & 0.5 & 180 \\
\hline Dense & $\mathrm{S} 14$ & $\begin{array}{l}24^{\circ} 16^{\prime} 22^{\prime \prime} \mathrm{S} \\
48^{\circ} 27^{\prime} 18^{\prime \prime} \mathrm{W}\end{array}$ & 12.5 & 128 & 6.51 & 15 & 30 & 55 & 10 & 840 & 0.4 & 180 \\
\hline Dense & S15 & $\begin{array}{l}24^{\circ} 16^{\prime} 20^{\prime \prime} \mathrm{S} \\
48^{\circ} 25^{\prime} 25^{\prime \prime} \mathrm{W}\end{array}$ & 13 & 204 & 6.3 & 45 & 10 & 40 & 5 & 840 & 0.6 & 180 \\
\hline Sugarcane & $\mathrm{S} 16$ & $\begin{array}{l}21^{\circ} 50^{\prime} 56^{\prime \prime} \mathrm{S} \\
48^{\circ} 08^{\prime} 10^{\prime \prime} \mathrm{W}\end{array}$ & 5.3 & 20 & 8.54 & 0 & 0 & 10 & 90 & 678 & 0.05 & 16 \\
\hline Sugarcane & S19 & $\begin{array}{l}22^{\circ} 33^{\prime} 51^{\prime \prime S} \\
47^{\circ} 36^{\prime} 51^{\prime \prime} \mathrm{W}\end{array}$ & 5.6 & 10 & 8.4 & 0 & 0 & 0 & 100 & 596 & 0.06 & 16 \\
\hline Sugarcane & S20 & $\begin{array}{l}21^{\circ} 52^{\prime} 03^{\prime \prime} \mathrm{S} \\
48^{\circ} 06^{\prime} 37^{\prime \prime} \mathrm{W}\end{array}$ & 5.2 & 80 & 9.3 & 0 & 0 & 0 & 100 & 693 & 0.05 & 16 \\
\hline Pasture & $\mathrm{S} 21$ & $\begin{array}{c}22^{\circ} 18^{\prime} 12^{\prime \prime} \mathrm{S} \\
47^{\circ} 40^{\prime} 14^{\prime \prime} \mathrm{W}\end{array}$ & 6.6 & 40 & 9.2 & 0 & 0 & 20 & 80 & 596 & 0.07 & 25 \\
\hline Pasture & $\mathrm{S} 22$ & $\begin{array}{l}22^{\circ} 14^{\prime} 19^{\prime \prime} \mathrm{S} \\
47^{\circ} 39^{\prime} 09^{\prime \prime} \mathrm{W}\end{array}$ & 7.3 & 210 & 9.2 & 0 & 10 & 10 & 80 & 622 & 0.07 & 25 \\
\hline Pasture & $\mathrm{S} 23$ & $\begin{array}{l}22^{\circ} 16^{\prime} 28^{\prime \prime} \mathrm{S} \\
47^{\circ} 57^{\prime} 45^{\prime \prime} \mathrm{W}\end{array}$ & 5 & 40 & 9.2 & 0 & 0 & 10 & 90 & 728 & 0.05 & 25 \\
\hline Pasture & S24 & $\begin{array}{l}22^{\circ} 02^{\prime} 15^{\prime \prime} \mathrm{S} \\
47^{\circ} 46^{\prime} 48^{\prime \prime} \mathrm{W}\end{array}$ & 6.7 & 20 & 8.2 & 0 & 5 & 0 & 95 & 898 & 0.07 & 25 \\
\hline Pasture & S25 & $\begin{array}{c}22^{\circ} 23^{\prime} 26^{\prime \prime} \mathrm{S} \\
47^{\circ} 45^{\prime} 10^{\prime \prime} \mathrm{W}\end{array}$ & 6.5 & 60 & 9.2 & 0 & 0 & 90 & 10 & 572 & 0.06 & 25 \\
\hline Eucalyptus & $\mathrm{S} 26$ & $\begin{array}{c}23^{\circ} 25^{\prime} 06^{\prime \prime} \mathrm{S} \\
46^{\circ} 46^{\prime} 26^{\prime \prime} \mathrm{W}\end{array}$ & 6.3 & 50 & 6.19 & 0 & 0 & 0 & 100 & 774 & 0.06 & 135 \\
\hline Eucalyptus & $\mathrm{S} 27$ & $\begin{array}{l}23^{\circ} 20^{\prime} 41^{\prime \prime S} \\
46^{\circ} 51^{\prime} 44^{\prime \prime} \mathrm{W}\end{array}$ & 6.9 & 140 & 6.7 & 0 & 10 & 0 & 90 & 754 & 0.07 & 135 \\
\hline Eucalyptus & S28 & $\begin{array}{l}23^{\circ} 19^{\prime} 27^{\prime \prime} \mathrm{S} \\
46^{\circ} 51^{\prime} 01^{\prime \prime} \mathrm{W}\end{array}$ & 8.5 & 100 & 6.9 & 0 & 0 & 0 & 100 & 720 & 0.08 & 135 \\
\hline Eucalyptus & S29 & $\begin{array}{l}23^{\circ} 21^{\prime} 13^{\prime \prime} \mathrm{S} \\
46^{\circ} 53^{\prime} 25^{\prime \prime} \mathrm{W}\end{array}$ & 7.1 & 29 & 7.8 & 0 & 0 & 0 & 100 & 726 & 0.07 & 135 \\
\hline
\end{tabular}

In total 2.592 mayfly nymphs were collected. distributed across six families and 25 genera (Table II). Among these, $44 \%$ of the genera were rare, with abundance less than $1 \%$. The rarefied richness was higher in pristine areas (21 genera), especially in mixed tropical rainforest and semideciduous seasonal forest, while much lower richness values were found in streams on agricultural land (9 genera), especially in sugarcane plantations (3 genera, Figure 2). Similar richness was found only in pasture and eucalyptus (Figure 2).

The NMDS ordination showed clear segregation of the streams located in land use vs. pristine areas (Figure 3), with significant differences on 
mayfly assemblages structure between the two landscape types (ANOSIM, R=0.67, $\mathrm{p}=0.001$ ). Pairwise tests showed similar assemblages structure between the different land use areas $(p>0.01)$ and assemblage structure dissimilar between the three pristine areas $(\mathrm{p}<0.01)$.

TABLE II

Taxonomic composition of Ephemeroptera sampled in pristine areas (mixed rainforest, semideciduous forest, dense rainforest) and land use areas (pasture, sugarcane, eucalyptus) in São Paulo state.

\begin{tabular}{|c|c|c|c|c|c|c|}
\hline Genera & $\begin{array}{c}\text { Mixed } \\
\text { Rainforest }\end{array}$ & $\begin{array}{c}\text { Semideciduous } \\
\text { Forest }\end{array}$ & $\begin{array}{c}\text { Dense } \\
\text { Rainforest }\end{array}$ & Sugarcane & Pasture & Eucalyptus \\
\hline \multicolumn{7}{|l|}{ BATIDAE } \\
\hline Americabaetis & 6 & 49 & 2 & 28 & 213 & 2 \\
\hline Apobaetis & 1 & 0 & 9 & 0 & 0 & 0 \\
\hline Baetodes & 12 & 13 & 0 & 0 & 0 & 1 \\
\hline Callibaetis & 0 & 0 & 0 & 2 & 141 & 1 \\
\hline Cloeodes & 1 & 0 & 0 & 0 & 0 & 0 \\
\hline Paracloeodes & 0 & 2 & 0 & 0 & 0 & 0 \\
\hline Tupiara & 1 & 0 & 0 & 0 & 0 & 0 \\
\hline Waltzoyphius & 0 & 0 & 0 & 0 & 1 & 13 \\
\hline Zelusia & 0 & 1 & 0 & 0 & 0 & 4 \\
\hline \multicolumn{7}{|l|}{ CAENIDAE } \\
\hline Caenis & 0 & 37 & 11 & 287 & 10 & 97 \\
\hline \multicolumn{7}{|c|}{ EUTHYPLOCIIDAE } \\
\hline Campylocia & 61 & 0 & 0 & 0 & 0 & 0 \\
\hline \multicolumn{7}{|c|}{ LEPTOPHLEBIIDAE } \\
\hline Farrodes & 21 & 212 & 52 & 0 & 13 & 0 \\
\hline Hagenulopsis & 2 & 0 & 0 & 0 & 0 & 0 \\
\hline Hermanella & 51 & 0 & 0 & 0 & 0 & 0 \\
\hline Hylister & 0 & 7 & 0 & 0 & 0 & 0 \\
\hline Massartella & 14 & 0 & 17 & 0 & 0 & 0 \\
\hline Miroculis & 0 & 46 & 0 & 0 & 0 & 0 \\
\hline Thraulodes & 54 & 10 & 0 & 0 & 0 & 0 \\
\hline Ulmeridoides & 0 & 0 & 2 & 0 & 0 & 0 \\
\hline \multicolumn{7}{|c|}{ LEPTOHYPHIDAE } \\
\hline Leptohyphes & 0 & 144 & 0 & 0 & 0 & 0 \\
\hline Leptohyphodes & 244 & 0 & 0 & 0 & 0 & 0 \\
\hline Traverhyphes & 0 & 176 & 2 & 0 & 25 & 0 \\
\hline Tricorythodes & 59 & 391 & 0 & 0 & 0 & 0 \\
\hline Tricorythopsis & 0 & 39 & 0 & 0 & 2 & 0 \\
\hline \multicolumn{7}{|c|}{ MELANEMERELLIDAE } \\
\hline Melanemerella & 3 & 0 & 0 & 0 & 0 & 0 \\
\hline Abundance & 530 & 1127 & 95 & 317 & 405 & 118 \\
\hline
\end{tabular}

A preliminary RDA, using a forward procedure (alpha-value of 0.05), selected four environmental variables that best explained assemblage structure, in decreasing order of importance: RCE, elevation, fine sediment and $\mathrm{pH}$. Additionally, five spatial descriptors (PCNM) were generated from the spatial variables based on geographic coordinates, but only three of these spatial descriptors (PCNM2, PCNM1 and PCNM3) were selected in the forward procedure for use as covariates in the partial RDA.

In the partial RDA, all the selected environmental variables were organized along the first RDA axis, and land elevation and fine sediment were correlated with axis II (Table III). 
A

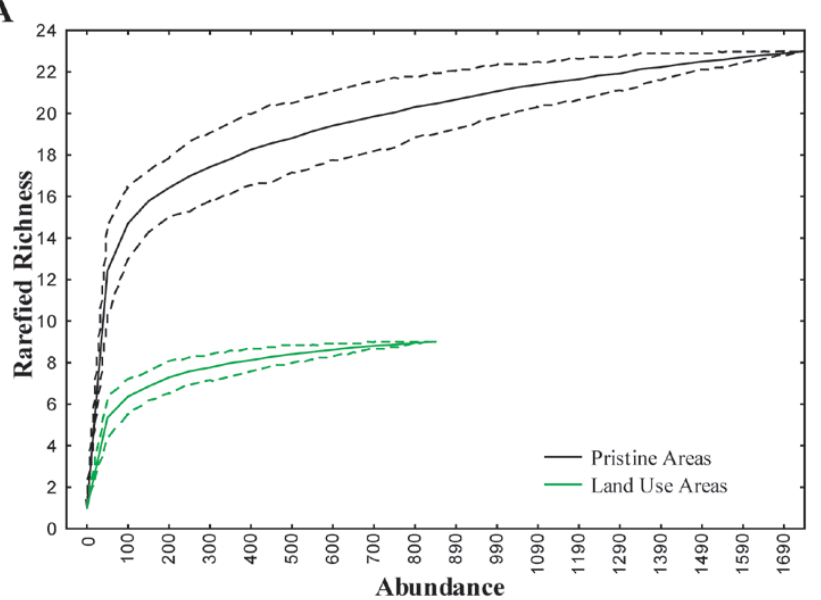

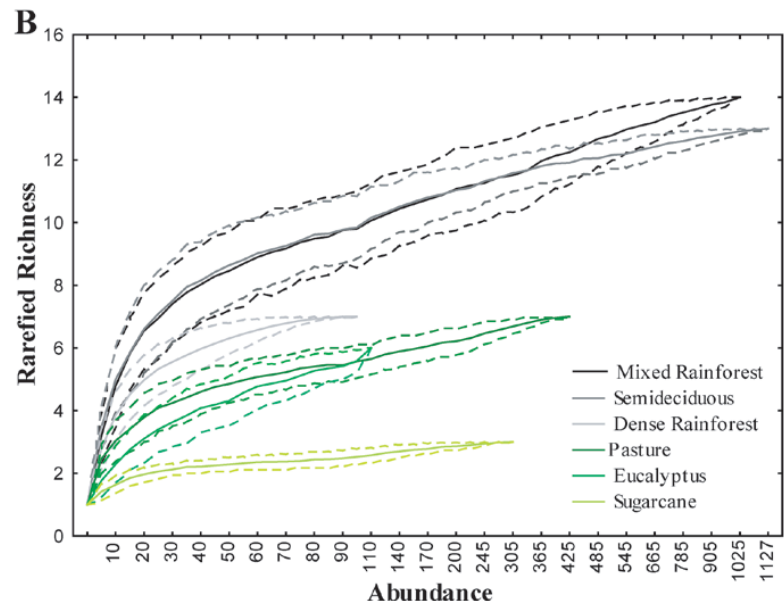

Figure 2 - Comparison of richness by the rarefaction method for streams in pristine versus land use areas in the state of São Paulo, Brazil in September 2006 and $2007(\mathrm{~N}=840$, left), and between streams in the six habitat types sampled ( $\mathrm{N}=95$, right). Continuous lines represent average richness and dashed lines represent the standard deviation around the average.

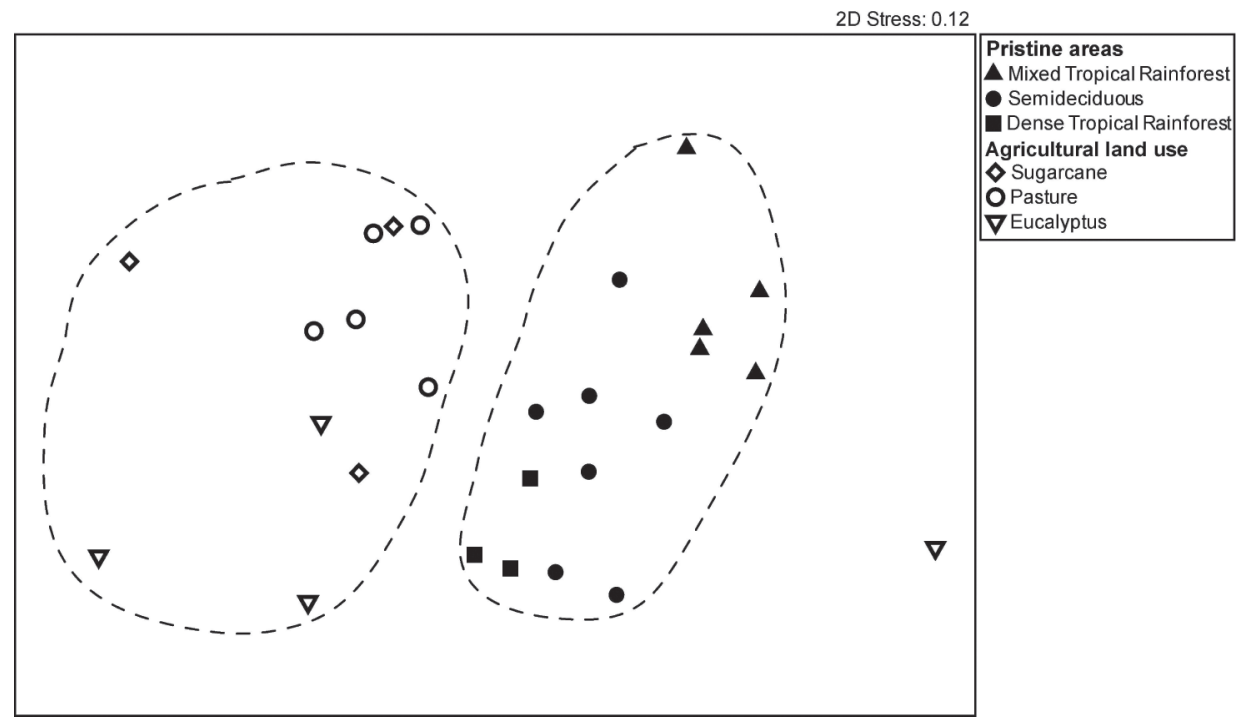

Figure 3 - Non-metric MDS plots of mayfly assemblages of pristine vs. land use areas in the state of São Paulo, Brazil using Hellinger-transformed and Bray-Curtis similarity measures. Filled symbols represent pristine areas and empty symbols represent land use areas. Dashed circles represent $12 \%$ similarity among pristine and land use samples.

TABLE III

Interset correlations of environmental variables included in model for axes I and II of the partial Redundancy Analysis.

\begin{tabular}{cccc}
\hline Environmental variables & Axis I & Axis II & $\mathrm{p}$ \\
\hline RCE & 0.90 & 0.12 & $<0.05$ \\
Fine sediment & -0.77 & 0.46 & $<0.05$ \\
$\mathrm{pH}$ & 0.68 & -0.08 & $<0.05$ \\
Land Elevation & 0.61 & -0.57 & $<0.05$ \\
\hline
\end{tabular}

The first and second axes of the pRDA explain $57.4 \%$ and $27.3 \%$ of the total variance, respectively and, the test of significance of first canonical axis was significant $(\mathrm{p}=0.002)$. The partial RDA biplot based on samples and environmental variables without the effect of spatial descriptors, indicated that the samples from pristine areas had higher RCE values while the streams in sugarcane, pasture 
and eucalyptus areas, had higher amounts of fine sediment and low RCE values (Figure 4 left). Mixed forest streams had the highest land elevation, and dense rainforest streams had the highest $\mathrm{pH}$
(Figure 4 left). The partial RDA biplot showed that Americabaetis,Callibaetis and Tricorythodes genera were associated with agricultural and forestry land streams (Fig. 4 right).
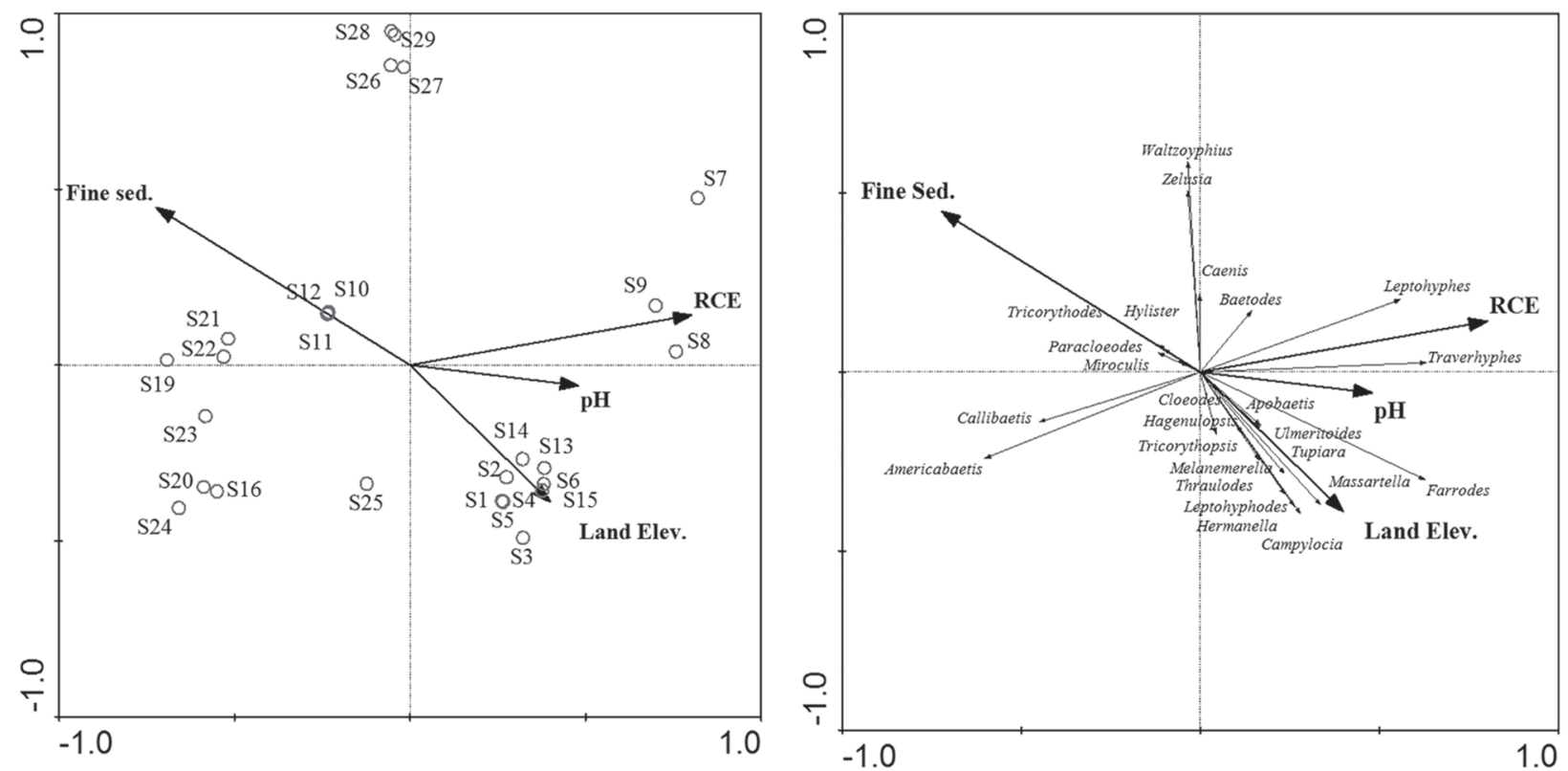

Figure 4 - Ordination diagrams of the first two axes of the partial redundancy analysis biplot including sample sites and environmental variables (RCE: Riparian Channel and Environmental Inventory; pH, fine sediment; land elevation) (left), and abundance of mayfly genera in pristine (S1 - S15) and agricultural and forestry land (S16 - S29) in São Paulo state (right). See Fig. 1 legend for site details. Variance of species-environment relation on axis $\mathrm{I}=57.4 \%$ and axis $\mathrm{II}=27.3 \%$.

\section{DISCUSSION}

Our results reinforce the importance of riparian forest for mayfly richness. Drastic reduction in richness $(57 \%)$ was recorded in streams draining agricultural landscapes, reflecting the harsh environmental conditions in these areas. Ephemeroptera richness in land used for sugarcane cultivation was reduced by $57 \%$ compared to streams in dense rainforest, and was reduced by $70 \%$ compared to streams in mixed rainforest and semideciduous forest.

Differences in mayfly assemblage structure between pristine and land use areas seem to be associated with the environmental complexity produced by riparian forest. It is known that streams running through natural vegetation landscapes maintain better biotic integrity and habitat heterogeneity than streams in which the surrounding forest is replaced by agricultural or urban land uses (Allan 2004). The input of allochthonous material from riparian forest provides nutrients and energy for the aquatic system, and also serves as habitat (e.g., leaves, branches, fruit) to be colonized, refuge from predators and oviposition sites for aquatic fauna (Dudgeon et al. 2006, França et al. 2009). Deforestation and replacement of native forest by exotic species can change the stream water quality, primary production and system dynamics, due to the input of sediments, fertilizers and pesticides. It can also increase light incidence, which alters water temperature and primary production (Allan 2004, Naiman et al. 2005), and likely affects other physio-chemical characteristics of the water, and assemblage structure.

Among the environmental habitat indicators measured, RCE values and substrate type, $\mathrm{pH}$ and 
land elevation were the explanatory variables best related to the differences in mayfly assemblage structure among the areas. The RCE was developed to assess physical and biological conditions of the riparian zone and channel morphology in small streams, a descriptor relevant to the colonization and permanence of invertebrates in aquatic systems (Petersen 1992). The high richness found in pristine areas and differences in assemblages structure can be explained by the high RCE scores and the heterogeneous substrate, composed of boulders, gravel and sand, as well as by the great accumulation of organic matter (e.g., leaves, branches).

Low RCE scores on agricultural and forestry lands are associated with precarious conservation of riparian vegetation, or its complete absence in some streams. Additionally the substrate in these areas consisted mainly of fine sediment, caused by bank erosion and runoff of sediment from adjacent land use areas. Substrate homogeneity combined with the poor condition of riparian vegetation best explains the low richness in land use streams.

Among the land uses, the lowest richness values were recorded on sugarcane plantation areas (only three genera) and low richness in general seems to be associated with the form of the cultivation of monoculture. Sugarcane is crop, where the soil is turned annually for planting and harvesting the culture. It is known that on sugarcane plantations, the use of fertilizers and pesticides containing heavy metals is widespread (AngelottiNetto et al. 2004). Heavy metal accumulation has a great impact on water resources, contaminating the water and sediment and entering the food chain of aquatic fauna; a study on the Jacaré-Guaçu River that flows through sugarcane plantations in São Paulo, reported reduced species richness and high level of heavy metal in the sediments and tissues of aquatic insects (Corbi and Froehlich 2010).

Riparian forest suppression enables sand and fine sediments to wash into streams, which causes streams to become silted, producing unstable habitats for organisms that rely upon stones and plant debris for shelter (Ferreira and Casatti 2006). The mayfly genera associated by partial RDA with fine sediment (Tricorythodes) and low RCE values (Americabaetis and Callibaetis) are likely to be tolerant to habitat changes and environmental disturbances caused by land use. These genera are known to colonize a wide variety of habitats. For example, nymphs of the genus Callibaetis can be found in rivers, streams or temporary waters with rocky or sandy substrate (Domínguez et al. 2009). Some species of Americabaetis are adapted to live in slow flowing water and bank vegetation (Salles 2006). Tricorythodes mainly dwell among banks or patches of sand, but can also be found in coarser substrate, or among algal filaments (Domínguez et al.2009). The Leptohyphes and Traverhyphes genera were associated with high RCE values, indicating that they are sensitive to disturbances due to agricultural and forestry activities. However, other genera were associated with land elevation and $\mathrm{pH}$ values (in this study due to rock formations), which demonstrates that features of natural variation are also predictors of mayfly distribution.

Among pristine areas, the low richness found in dense rainforest streams appears to be a reflection of water alkalinity of the streams sampled in Parque Estadual Intervales. The stream's $\mathrm{pH}$ values can be determined by the soil composition of the drainage basin. The alkaline $\mathrm{pH}$ of streams reflect the type of soil found in the Serra Paranapiacaba, which is karstic with outcrops of limestone and high concentrations of bicarbonate ions (Mantovani 1994). The lower species richness found in dense rainforest streams may also be a reflection of lower sampling efforts compared to other pristine areas.

Land elevation is another factor that can affect assemblage organization of many organisms, including aquatic insects, through their relation to the water temperature (Vinson and Hawkins 1998). Water temperature directly affects organism development, so that some groups occur preferentially between 
certain altitudinal zones above sea level (Domínguez and Valdez 1992). Among the streams studied here, the lowest temperature and the highest elevation (average of $1,550 \mathrm{~m}$ ) was recorded in mixed rainforest (Parque Estadual de Campos do Jordão), which could have affected the assemblages structure, especially considering the fact that some genera were only recorded in this area (Campylocia, Tupiara, Hagenulopsis, Hermanella, Leptohyphodes and Melanemerella). Nymphs of the genus Hermanella seem to be most represented in high altitude regions (Raimundi et al. 2013), however there is no information available on the others. These result emphasize that the mountainous regions of state of São Paulo harbor a high diversity of aquatic insects, as was previously demonstrated in studies in the Parque Estadual de Campos do Jordão with Trichoptera (Spies and Froehlich 2009), Ephemeroptera (Siegloch et al. 2012) and Coleoptera (Segura et al. 2012).

In summary, the drastic reduction of mayfly richness in streams located in land use areas, particularly in sugarcane plantation highlights the negative impact of conversion of pristine forest for agricultural and forestry purposes. This result reinforces the importance of maintaining pristine areas for conservation of biodiversity and water resources. Streams flowing through pristine vegetation sustain high richness, mainly due to the input of allochthonous organic matter (which provides food and shelter) and low bank erosion and siltation. Furthermore, the data reinforce the use of mayflies as environmental indicators, since many genera were sensitive to landscape changes (caused by either human activities or natural in origin) and responded to environmental gradients.

\section{ACKNOWLEDGMENTS}

We are grateful to Fundação de Amparo à Pesquisa do Estado de São Paulo (FAPESP) (project 05/597784) and to Coordenação de Aperfeiçoamento de Pessoal de Nível Superior (CAPES). This work is part of a thematic project within the BIOTA/ FAPESP program: The Biodiversity Virtual Institute Program (www.biota.org.br) "Levantamento e Biologia de Insecta e Oligochaeta Aquáticos de Sistemas Lóticos do Estado de São Paulo" (project 2003/10517-9).

\section{RESUMO}

O objetivo deste estudo foi testar o efeito do uso do solo para agricultura e silvicultura na estrutura das comunidades de Ephemeroptera em riachos de baixa ordem. Vinte e nove riachos foram investigados no estado de São Paulo. Nós analisamos 15 riachos em áreas pristinas (floresta ombrófila mista, semidecídua e floresta ombrófila densa) e 14 riachos com canade-açúcar, eucalipto e pastagem. A riqueza de Ephemeroptera obtida pelas curvas de rarefação foi maior nos riachos pristinos (21 gêneros), especialmente na floresta ombrófila mista e semidecídua quando comparada com os de uso do solo, particularmente menor na plantação de cana-de-açúcar (3 gêneros). A ordenação do escalonamento multidimensional não-métrico (NMDS) mostrou clara diferença nas comunidades de Ephemeroptera entre áreas de uso do solo e pristinas, suportada pela análise de similaridade ( $\mathrm{R}=0.67, \mathrm{p}=0.001)$. Na análise de redundância parcial (pRDA), os descritores ambientais que melhor explicaram as diferenças na estrutura da comunidade foram os valores do protocolo Riparian, Channel and Environmental Inventory (RCE), porcentagem de sedimento fino no substrato, $\mathrm{pH}$ e altitude. Nossos resultados mostraram que o uso do solo para agricultura e silvicultura tem um forte efeito negativo na estrutura das comunidades de Ephemeroptera. Estes resultados confirmam o uso de Ephemeroptera como indicadores ambientais, uma vez que alguns gêneros foram sensíveis às mudanças no uso do solo, enquanto outros responderam as alterações que ocorrem naturalmente na área de estudo.

Palavras-chave: Mata Atlântica, integridade ambiental, Ephemeroptera, riqueza, insetos aquáticos. 


\section{REFERENCES}

ALlan JD. 2004. Landscapes and Riverscapes: the influence of land use on stream ecosystems. Annu Rev Ecol Evol Syst 35: 257-284.

Angelotti-Netto A, Crestana S, De Oliveira SC AND BARBosa RVR. 2004. Bacia Hidrográfica. São Carlos: Rima Editora, p. 1-14.

BAIN MB AND STEVENSON NJ. 1999. Aquatic habitat assessment: Common methods. Bethesda, Maryland: American Fisheries Society, $136 \mathrm{p}$.

BORCARD D AND LEGENDRE P. 2002. All-scale spatial analysis of ecological data by means of principal coordinates of neighbour matrices. Ecol Model 153: 51-68.

CLARKE KR AND GORLEY RN. 2006. Primer v.6: User Manual/ Tutorial. PRIMER-E.

Clarke KR AND Warwick RM. 2001. Change in Marine Communities: An Approach to Statistical Analysis and Interpretation. $2^{\text {nd }}$ edition. Primer-E: Plymouth, UK.

Corbi JJ AND Froehlich CG. 2010. Bioaccumulation of metals in aquatic insects of streams located in areas with sugar cane cultivation. Quím Nova 33(3): 644-648.

Corbi JJ, Kleine P And Trivinho-Strixino S. 2013. Are aquatic insect species sensitive to banana plant cultivation. Ecol Indic 25: 156-161.

CORBI JJ AND TRIVINHO-STRIXINO S. 2008. Relationship between sugar cane cultivation and stream macroinvertebrate communities. Braz Arch Biol Technol 51: 769-779.

Corbi JJ, TRIVINHO-StriXino S, SANTOS A AND DEl GRANDE M. 2006. Environmental diagnostic of metals and organochlorated compounds in streams near sugar cane plantations activity (State of São Paulo, Brazil). Quím Nova 29: 61-65.

DOMÍNGUEZ E AND FERNÁNDEZ HR. 2009. Macroinvertebrados bentónicos sudamericanos: sistemática y biología. Tucumán: Fundación Miguell Lillo, 656 p.

Domínguez E, Molineri C, Pescador M, HubBard M AND NIETO C. 2006. Aquatic Biodiversity in Latin America: Ephemeroptera of South America. Volume 2, Moscow: Pensoft, $646 \mathrm{p}$.

DOMÍNGUEZ E AND VALDEZ JMB. 1992. Altitudinal replacement of Ephemeroptera in a subtropical river. Hydrobiologia 246: 83-88.

DudGEON D ET AL. 2006. Freshwater biodiversity: importance, threats, status and conservation challenges. Biol Rev 81: 163-182.

FERNÁNDEZ HR, ROMERO F AND DOMÍNGUEZ E. 2009. Intermountain basins use in subtropical region and their influences on benthic fauna. River Res Appl 25: 181-193.

FERREIRA CP AND CASATTI L. 2006. Influência da estrutura de habitat sobre a ictiofauna de um riacho em micro-bacia de pastagem, São Paulo, Brasil. Rev Bras Zool 23: 642-651.

França JS, GREGório RS, PAULA JD, GONÇALVES JÚNIOR JF, Ferreira FA AND CAllisto M. 2009. Composition and dynamics of allochthonous organic matter inputs and benthic stock in a Brazilian stream. Mar Freshwater Res 60: 990-998.
GOTELLI NJ AND ENTSMINGER GL. 2001. EcoSim: Null models software for ecology. Version 7.0 Acquired Intelligence Inc. \& Kesey-Bear. Available from http://homepages.together. net $\sim$ gentsmin/ecosim.htm (accessed 15 January 2012).

Kleine P, TRIVINHO-StrixinO S AND CORBI JJ. 2012. Relationship between banana plant cultivation and stream macroinvertebrate communities. Acta Limnol Bras 23(4): 344-352.

MAgURRAn AE. 2011. Medindo a diversidade biológica. Curitiba: UFPR, $262 \mathrm{p}$.

Mantovani W. 1994. A paisagem dinâmica. In: Leonel C (Ed), Intervales. Fundação para a Conservação a Produção Florestal do Estado de São Paulo, Governo do Estado de São Paulo, Secretaria do Meio Ambiente, São Paulo, p. 81-100.

Moulton TP, Souza ML, Silveira RML AND Krsulović FAM. 2004. Effects of ephemeropterans and shrimps on periphyton and sediments in a coastal stream (Atlantic forest, Rio de Janeiro, Brazil). J N Am Benthol Soc 23: 868-881.

Myers N, Mittermeyer RA, Fonseca GAB AND Kent J. 2000. Biodiversity hotspots for conservation priorities. Nature 403: 853-858.

NAIMAN RJ, DÉCAMPS H AND MCCLAIN ME. 2005. Riparia: ecology, conservation, and management of streamside communities. Burlington: Elsevier Academic Press, 448 p.

Nessimian JL, Venticingue EM, ZuAnon J, De Marco JR P, GORDO M, FIDELIS L, BATISTA JD AND JUEN L. 2008. Land use, habitat integrity, and aquatic insect assemblages in Central Amazonian streams. Hydrobiologia 614: 117-131.

PETERSEN JR RC. 1992. The RCE: A riparian, channel, and environmental inventory for small strems in the agricultural landscape. Freshwater Biol 27: 295-306.

RAIMUNDI EA, SALles FF AND SOUZA-Franco GMS. 2013. Fauna of Leptophlebiidae Banks (Insecta: Ephemeroptera) on fragments of the Atlantic Forest from west region of Santa Catarina State, Brazil. Biota Neotrop 13(4): 57-70.

RANGEl TF, DinIZ-FILHO JAF AND BINI LM. 2010. SAM: a comprehensive application for Spatial Analysis in Macroecology. Ecography 33: 46-50.

Ribeiro MC, MetzGer JP, MARTENSEN AC, PONZONI F AND HiRotA MM. 2009. Brazilian Atlantic forest: How much is left and how is the remaining forest distributed? Implications for conservation. Biol Conserv 142: 1141-1153.

ROSENBERG DM AND RESH VH. 1993. Freshwater monitoring and benthic macroinvertebrates. New York: Chapman \& Hall, 504 p.

SALLES FF. 2006. A ordem Ephemeroptera no Brasil: taxonomia e diversidade. Faculdade Federal de Viçosa, 300 p. Tese de doutorado.

SALLES FF, DA-SILVA ER, SERRÃo JE AND FRANCISCHETTI CN 2004. Baetidae (Ephemeroptera) na Região Sudeste do Brasil: novos registros e chave para os gêneros no estágio ninfal. Neotrop Entomol 33: 569-576.

SEgura MO, FonseCA-Gessner A, SPIES MR AND SIEGLOCH AE. 2012. Water beetles in mountainous regions in southeastern Brazil. Braz J Biol (Impr.) 72: 311-321. 
SIEGloch AE, Froehlich CG AND SPIES MR. 2012. Diversity of Ephemeroptera (Insecta) of the Serra da Mantiqueira and Serra do Mar, southeastern Brazil. Rev Bras Entomol (Impr.) 56: 473-480.

SOS MATA ATLÂNTICA/INPE. 1993. Atlas da evolução dos remanescentes florestais da Mata Atlântica e ecossistemas associados no período de 1985-1990. São Paulo: SOS Mata Atlântica/INPE.

SPIES MR AND FroeHLICH CG. 2009. Inventory of caddisflies (Trichoptera: Insecta) of the Campos do Jordão State Park, São Paulo State, Brazil. Biota Neotropica 9(4): 211-218.
Suriano MT, FonseCA-GeSSNER AA, RoQue FO AND Froehlich CG. 2010. Choice of macroinvertebrate metrics to evaluate stream conditions in Atlantic Forest, Brazil. Environ Monit Assess 175: 87-101.

TER BRAaK CJF AND SMILAUER P. 2002. Canoco for Windows, Version 4.5. Biometris, Wageningen-UR.

VINSON MR AND HAWKINS CP. 1998. Biodiversity of stream insects: variation at local, basin and regional scales. Ann Rev Entomol 43: 271-293.

WARD JV. 1992. Aquatic insect ecology: biology and habitat. United States of America: J Wiley \& Sons, 438 p. 
